\title{
Russia-Spain Cooperation on Counter-Terrorism: New Challenges or Old Problems?
}

\author{
Svetlana Bokeriya ${ }^{1}$
}

Recibido: 03-10-2017 / Aceptado: 25-09-2019

\begin{abstract}
Against the backdrop of globalization, international terrorism is becoming a complex threat, which can be countered only by the united efforts of all countries. The level of cooperation of states does not fully correspond to the scale of the world terror challenge. Cooperation in the fight against terrorism at the bilateral level opens up more opportunities because it is based on mutual trust between States, with greater effectiveness, as well as practical impact and benefits, due to the knowledge of the situation and the ability to respond quickly. The inefficiency of the global counterterrorism system can be compensated by the mechanism of bilateral cooperation in the sphere of counter-terrorism, despite all the existing problems such as: sanctions, human rights, the need to promptly equate national laws and legislation in line with international laws, etc. The choice of the Russian Federation and Spain as a case study for this research is not accidental, since the interaction of both countries allows us to trace the development of mechanisms and instruments to counter terrorism on a bilateral basis. As a result of the comparative analysis, it is established that while Russian-Spanish relations began to deteriorate in 2014 as a result of the sanctions policy, the bilateral contexts of cooperation in the field of countering extremism have become comparable in two parameters: the overall level of the threat of terrorism in Russia and Spain, as well as the types of terrorist challenges on their territory.
\end{abstract}

Keywords: bilateral cooperation; terrorism; counter-terrorism strategy; Russia; Spain; UN; international relations; globalization; contractual legal framework; sanctions.

\section{[es] Cooperación ruso-española contra el terrorismo: ¿nuevos desafíos o problemas viejos?}

Resumen. El nivel de cooperación entre las naciones por ahora no concuerda con la escala del problema que abarca el terrorismo internacional. Sin embargo, la interacción en la lucha contra el terrorismo a nivel bilateral abre nuevas posibilidades en virtud de que se basa en la mutua confianza entre las naciones. Tiene un gran resultado y también es eficaz. Se caracteriza por tener conocimiento de la situación en el lugar y contar con la posibilidad de reaccionar rapidamente en conjunto. La inefectividad del sistema global de contraterrorismo puede ser compensada por el mecanismo de cooperación bilateral en el campo de la contraposición al terrorismo, a pesar de todos los problemas existentes: sanciones, derechos humanos, la necesidad de poner operativamente la legislación nacional en correspondencia con los actos territoriales, etc. La elección de la FR y de España como case-status para llevar a cabo este estudio no es casual, ya que el contenido de la interacción entre estos países permite velar por el desarrollo de los mecanismos y los instrumentos de contraposición al

\footnotetext{
1 People's Friendship University of Ruisia, RUDN (Rusia).

E-mail: petrovsvet@yandex.ru
} 
terrorismo en una base bilateral. Como resultado de un análisis comparativo, se estableció que al mismo tiempo que las relaciones ruso-españolas comenzaron a empeorar en el año 2014, a causa de la política de sanciones, los contextos recíprocos de interacción en el campo de contraposición al extremismo llegaron a compararse en dos índices: según el nivel general de amenaza de terrorismo en Rusia y en España, y según los tipos de desafíos terroristas en sus territorios.

Palabras clave: cooperación bilateral; terrorismo; estrategia contra el terrorismo; Rusia; España; ONU; relaciones internacionales; globalización; marco contractual legal; sanciones.

Cómo citar: Bokeriya, S. (2019): "Russia-Spain Cooperation on Counter-Terrorism: New Challenges or Old Problems?”, Política y Sociedad, 56(3), pp. 737-756.

Sumario. 1. Introduction. 2. Conceptual Approaches of the EU to International Security and Terrorism. 3. UN Activity in Counter-Terrorism. 4. Russia-Spain Cooperation to Counter-Terrorism: Challenges and Legal Approaches. 5. Conclusion. 6. Bibliography.

Acknowledgements. This paper was financially supported by the Ministry of Education and Science of the Russian Federation on the program to improve the competitiveness of Peoples' Friendship University of Russia (RUDN University) among the world's leading research and education centers in the 2016-2020.

\section{Introduction}

A distinctive feature of the modern period of development of the world community was the aggravation of global problems, challenges and threats at the turn of the twentieth and twenty-first centuries, requiring a collective and coordinated response. These problems have become factors that determine not only the key trends in the development of international relations, but also the main directions of world politics, as well as the international agenda.

Against the background of fundamental and dynamic changes that affect the interests of each State, the formation of new political blocs, as well as the economic crisis and globalization processes, blurring the boundaries between the center and the periphery, foreign and domestic policies of States, the problems of protecting a global society, each individual nation and person from complex interdependent challenges and threats are becoming more acute.

New challenges and threats, such as international terrorism, drug trafficking, global poverty, organized crime, regional conflicts and illegal migration, are global in scale and complex, quickly transforming and changing, requiring rapid response and preventive measures. The situation is aggravated by the fact that these threats can come from both non-state actors and States. All this, on the one hand, destabilizes the international system, on the other hand, activates and intensifies international and regional cooperation between States, which should become a key motive and an effective way to confront complex challenges and threats.

Terrorism statistics shows a temporal growth. According to the latest international report Global Terrorism Index 2018, analyzing the impact of terrorism for 163 countries and which covers 99.7 per cent of the world's population, every region in the world recorded a higher average impact of terrorism in 2017 than in 2002. The increase in the impact of terrorism was greatest in the Middle East and North Africa, followed by sub-Saharan Africa. In Western 
Europe, deaths fell by 52 per cent, from 168 in 2016 to 81 in 2017. From January until October 2018, fewer than ten deaths were recorded in the region.

Despite the fall in deaths, the number of incidents rose in Western Europe. Increased counter-terrorism spending and security measures have reduced the lethality of attacks. In 2017, just under 95 per cent of total deaths from terrorism occurred in countries involved in at least one violent conflict. When countries in conflict are combined with countries with high levels of political terror, the number climbs to 99 per cent. Terrorist attacks in conflict-affected countries are also more lethal, killing 2.4 people per attack on average, compared to 0.84 people in nonconflict countries in 2017 (Global Terrorism Index, 2018).

This article seeks to provide an analysis of the international terrorism impact on global security with particular emphasis to Russia-Spain bilateral interaction as a part of counter-terrorism efforts on a multinational level. The article is divided into 6 sections, including introduction, conclusion, and bibliography. The first section features conceptual approaches to international security and terrorism of the European Union. The second section addresses and analyses the UN counterterrorism strategy that requires updating with due regard to the current circumstances. The third section represents an analysis of bilateral cooperation between Russia and Spain with regard to counter-terrorism efforts in order to illustrate the influence of terrorist attacks on national policies, and the cooperation dynamics, and to estimate the established mechanism of bilateral cooperation with regard to the struggle against this threat.

\section{Conceptual Approaches of the EU to International Security and Terrorism}

In the context of reviewing the conceptual aspects of counter terrorism, special attention should be paid to the analysis of challenges, key trends and gaps in the counter-terrorism approaches of the EU, of which Spain is a member.

The EU's antiterrorist activities rightfully play a key role in shaping the international legal framework of the European security system in the sphere of countering the threat of terrorism, because creating a security zone, freedom and justice is one of the main objectives of the Union.

The following events had a significant impact on the development of the EU's counter-terrorism program: 1) the September 11, 2001 terrorist attacks in the United States. Ten days after these events, at an extraordinary meeting, the European Council declared the fight against terrorism a priority for the EU; 2) the Madrid bombing in 2004 and London in 2005; 3) the Syrian war and the emergence of ISIS; 4) the attacks in Nice and Berlin in 2016 and the crimes involving lone terrorists (The European Union's Policies on Counter-Terrorism, 2017). A common feature of these attacks was the connection with Islamic terrorism, which is why it has become a key focus of the anti-terrorist struggle in the EU. Over the past decade, there has been an increase in the number of terrorist acts of right-wing and jihadist extremism against the backdrop of a decline in separatist and left-wing extremist protests. The trend in recent years has been the increase in terrorist attacks by lone terrorists, as well as active propaganda activities through the internet, with the aim of recruiting new members and 
organizing terrorist acts. According to Deputy Secretary of the Security Council of the Russian Federation Yuri Kokov, "today there are about 30 thousand extremist and terrorist sites. The era of technological and digital terrorism is coming, which in terms of the scale of the consequences in the near future can be comparable with weapons of mass destruction" (Tarasenko, 2019).

However, with the earlier use of internet, members of the Islamic state group urged their supporters to move to Syria and Iraq to commit terrorist attacks, now they are offered to commit Jihad in Western countries, where they are. The fact that this appeal was accepted, the terrorist attacks in Norway, the Netherlands, France and Spain in 2019, among other things, is a confirmation.

Cooperation within the EU in the fight against terrorism before the terrorist attack of September 11, 2001 was not an official part of the institutional architecture of the European Union. The "European Union counter-Terrorism strategy", adopted after the London bombing on 7 July 2005, was not aligned with comprehensive strategies (in particular, internal and external security of EU countries) and sub-strategies aimed at countering the financing of terrorism, radicalization and recruitment. Later in 2008, the Council adopted the EU strategy against radicalization and recruitment of terrorists.

Since 2013, the issues of radicalization and the fight against terrorists became permanent items in the agenda of the EU Council and the Council of Europe. The provisions and main tasks for internal and external counter-terrorism activities were developed.

In 2015, EU leaders declared the need to expand cooperation with third world countries in the area of security and the fight against terrorism.

Furthermore, the "European Security Agenda" was then initiated, which focused on the exchange of information between States and the prevention of radicalization, created after the attacks in Brussels in March 2016. The concept of "Security Agenda", highlighted the important transition from protecting of a country's internal security to protecting the collective security of the EU as a whole (European Commission, 2016: 2, 9).

One of the difficulties in developing conceptual frameworks for anti-terrorism in the EU has been the large number of participants (the EU, the EU Council and the European Commission) involvement in this process, as well as duplication and the intersection of tasks, which significantly complicates and slows down the formation of structural and integrated approach. This, in turn, plays into the hands of terrorists, since the system of counteraction against radicalization and terrorism cannot respond to quickly transforming challenges and threats.

In March 2017, the Council adopted a directive on counter-terrorism, which provides for responsibility for such actions as: conducting training or travelling for terrorist purposes, organizing or facilitating such a trip, as well as providing or collecting funds directed to terrorist groups or their activities. However, there is a critical point of view based on the fact that this directive, due to its broad interpretation and general nature, can exacerbate the problem of human rights violations: criminalize public protests and other peaceful actions, suppress freedom of expression, including opposition political views. There are concerns that the directive will be applied at the national level to discriminate against vulnerable and marginalized ethnic and religious communities (Aoláin, 2018). 
Also in 2017, a resolution was adopted to amend the code of Schengen territory and to strengthen the verification of relevant databases at external borders. It requires member States to systematically review relevant databases for all persons crossing external borders. In April 2017, the Council signed a directive on the control of the acquisition and possession of weapons, containing measures to strengthen the control of firearms and prevent its use.

Analyzing the development of counter-terrorism architecture of the EU has shown that the main incentive for the elaboration of legal acts regulating the fight against terrorism were the terrorist acts, committed at short intervals in different European countries. It can be said that such an approach involves taking measures after the fact, and not for the future.

In addition, threats are not updated on a regular basis within the EU. In particular, Europol and the EU Intelligence and Situation Center are engaged in threat assessment on a situational basis, not comprehensively and not on an ongoing basis. The emphasis in anti-terrorist strategies on jihadism leads to underestimation of threats from other extremist movements, for example, far-right radicals.

In parallel with the adoption and application of a large number of strategies, legal mechanisms and tactics in the field of anti-terrorism, the problem of human rights protection is becoming increasingly acute, which at first glance is not obvious. However, in the broad legal field of counter-terrorism, there is a cumulative effect of the joint action of various norms and measures affecting freedom of movement, expression of opinion, the right to hold rallies and speeches of peaceful citizens of a state (Aoláin, 2018).

Human rights can be violated even at the level of data collection, as confidentiality and data protection are not sufficiently regulated. Among the authorities of various States, guided by both national and international legal acts, there is no clear understanding of the rights of persons who hold confidential data. In the case of a terrorist threat, data collection often covers a wide range of people (family members, representatives of religious communities and public associations). The result of the information exchange for a person who possesses classified or secret information, may include surveillance (often unknown to the subject), consequences associated with further employment, restrictions on border crossings, as well as control or blocking access to financial resources for individuals and families.

Thus, the EU's counter-terrorism system is multilateral, but not yet completed and requires improvement in terms of ensuring and developing human rights, updating the list of threats, collecting and evaluating data, as well as a clearer delineation of tasks within the authorized structures. However, a common understanding of the need to apply a consolidated approach to solving the problem of terrorism and extremism should be a key motive for cooperation between the EU and Russia, which shares this approach.

\section{UN Activity in Counter-Terrorism}

The bilateral Russian-Spanish cooperation cannot be entirely analyzed without the best practices elaborated by the most powerful international organization in the 
field of countering international terrorism - the UNO. The main UN counterterrorism bodies are a group of organizations working under the aegis of the General Assembly (UN GA), as well as the Security Council (UN SC). However, counter-terrorism tasks given in the mandates of these organizations sometimes coincide, despite their different specialization, which hinders coherence of the UN activities generally in this field and requires optimization of resources and reformation of the UN hierarchical system.

The UN Security Council established the Counter Terrorism Committee after the 9/11 terrorist attack and approved resolution 1373 (2001), devoted to measures in fighting against terrorism. The UN Security Council adopts resolutions and is responsible for the Counter-Terrorism Strategy, as well as the UN General Assembly that consolidates and coordinates the UN Global Counter-Terrorism Strategy. This Strategy was adopted on 8 September 2006. Russia and Spain contributed to its adoption by consensus. The Global Counter-Terrorism Strategy in the form of a resolution and the Plan of Action (A/RES/60/288) are composed of four pillars, which are addressing the conditions conducive to the spread of terrorism; measures to prevent and combat terrorism; measures to build states' capacity and to strengthen the role of the United Nations system in that regard; measures to ensure respect for human rights and the rule of law.

The Resolution proposes certain measures to prevent and eliminate conditions contributing to the spread of terrorist activities. In particular, to examine the question of creating national systems of assistance that would promote the needs of victims of terrorism and their families and facilitate the normalization of their lives; to establish an international center for counter-terrorism; to use the experience of similar international, regional and sub-regional organizations with the aim to exchange the cutting-edge experience in the field of strengthening potential in countering terrorism and many other. The Strategy is being implemented via the UN agencies - the UN Secretariat, the UN Security Council and observers - 38 bodies in total (UN Office of Counter-Terrorism, 2019a).

Moreover, the UN Secretary-General proposed to institutionalize the CounterTerrorism Implementation Task Force within the Secretariat in order to ensure overall coordination in the United Nations system's counter-terrorism efforts.

There have been adopted $26 \mathrm{UN}$ resolutions (13 of them were adopted by the GA and the same quantity by the SC) devoted to the counter-terrorism subject and their number increases annually, which attests to the fact that high global attention is given to this problem: Resolution 70/291, which is the UN Global CounterTerrorism Strategy; Resolution 71/38 highlights the measures to prevent terrorists from acquiring weapons of mass destruction; Resolution 71/67 on Nuclear Disarmament Verification; Resolution 71/151 highlighted the measures to eliminate international terrorism. In addition, the following resolutions of the UN Security Council are to be included in this list: 2309 (2016) devoted to the terrorist threats to civil aviation; 2331 (2016) —on combating human trafficking and terrorism, as well as 2341 (2017) - on protecting critical infrastructure against terrorist attacks (UN Office of Counter-Terrorism, 2019b).

It is noteworthy that resolution 71/151 adopted by the UN General Assembly has included recommendations to all member states to accelerate the process of solving the unsettled tasks associated with development of a draft Comprehensive 
Convention on International Terrorism, whose elaboration started in December 1999 after adopting Resolution 54/110 by the UN General Assembly. However, its preparation is complicated by the lack of consensus among the experts on certain questions. At the moment, the project exists only in the form of a working paper.

The first key institutional reform initiated by the Secretary-General was the establishment of the United Nations Office of Counter-Terrorism in June, 2017. The Office is aimed at cooperation with Security Council bodies and member states, strengthening current and developing new partnerships through regular attendance at counter-terrorism-related meetings, enhancing coordination across the 38 Counter-Terrorism Implementation Task Force entities to provide the balanced implementation of the 4 pillars of the UN Global Counter-Terrorism Strategy. At the request of member states the UN Office of Counter-Terrorism via its UN Counter-Terrorism Centre is already implementing over 40 counterterrorism capacity-building projects. For instance, the initiative for assisting young people to become resilient to radicalization in Bangladesh and Pakistan (United Nations Office in the Russian Federation, 2018).

The Secretary-General signed the new United Nations Global CounterTerrorism Coordination Compact in February 2018, which changes the CounterTerrorism Implementation Task Force coordination mechanism.

Despite of the first steps in the UN counter-terrorism system reforming and having a wide range of relevant tools in the UN framework, why isn't the international security system functioning regardless?

Nevertheless, the existing international regulatory framework is not sufficiently efficient. The reason is that conventions define and regulate only separate aspects for combating terrorism. That means they are of a sectoral nature, which, in its turn, makes it impossible to solve the problem comprehensively. Additionally, the UN's line of work can be characterized by piecemeal approaches and by the tendency to create special-purpose committees and plans of action following on from the result of certain incidents, and not by creation of a coordinated program. Furthermore, there is a duplication of tasks within the framework of different agencies that indicates the necessity of optimization and reformation of the UN system in order to increase the efficiency of its activity. Besides, there is no a unified definition of the terms international terrorism, terrorist attack and terrorism, that fact hinders the creation of international treaty obligations framework and gives the states an opportunity to manipulate the terms for their purposes. For example, the term terrorism has multidisciplinary nature, connecting such interpretations as computer attacks, politically-motivated murders, war crimes, etc. There is no global agreement on the definition of terrorism under the UN. The European Union documents present no universal definition for the term as well.

During the High-level Conference in Counter-terrorism, held in June 2018 in New York, António Guterres, the United Nations Secretary-General explained that the "terrorism threat continued to evolve and the international community needed to adapt and learn lessons from what worked and what did not. There is a need to strengthen the capacities of counter-terrorism structures and institutions and build the resilience and cohesion of societies at national and regional levels" (Report of the United Nations High-level Conference in Counter-terrorism, 2018). He also noted the major goals for combating terrorism: strengthening international counter- 
terrorism cooperation, a renewed and sustained focus on preventing terrorism, underlining the importance of fully respecting human rights while tackling terrorism, reinforcing the need to make a strategic investment in young people to counter terrorism and prevent violent extremism, shining a light on the tragic human cost of terrorism, and strengthening the role of the United Nations to assist member states in tackling terrorism. According to Report of the United Nations High-level Conference in Counter-terrorism 2018, the goals show the concerted approaches to the problems of counter-terrorism, which should be solved via an "all-of-government", "all-of-society" and "all-of-UN" mechanisms.

In the framework of common efforts, Spain and Russia are actively involved in developing the conceptual framework for combating international terrorism under the auspices of the UN. Thus, For example, Spain is participating in the "Special Counter-Terrorism Strategy Group", particularly active in the Victim Support Group of Terrorism, which is a significant aspect of the post-conflict settlement. Spain has contributed to the adoption of measures and resolutions of importance in the fight against terrorism. These include the adoption of July 2015 Madrid Guidelines on the control of the movement of foreign terrorist fighters and UN Security Council resolution 2322 of December 2016 on international judicial and police cooperation in matters of terrorism.

In 2017, Spain played a key role in the UN General Assembly resolution (A/C.3/72/L.24), which declared $21^{\text {st }}$ of August the International Day of Remembrance of the victims of terrorism. Spain has one of the most progressive systems of support for victims of terrorism (Argomaniz, 2015).

During Spain's presidency of the UN Security Council, Spain introduced Resolution 2331 on human trafficking in conflict situations and contributed to the approval of the UNGA Resolution (A/RES/71/322) on "Strengthening and promoting effective measures and international cooperation in organ donation and transplantation to prevent and combat human trafficking".

In 2017, an Anti-Terrorism Bureau was set up to strengthen the UN's counterterrorism structure, headed by Russian diplomat Vladimir Voronkov. In 2018, he signed the UN Global coordination Pact on combating terrorism (the "Global compact") along with 36 divisions of the Organization, Interpol and the World Customs Organization. Its goal is to improve coordination and coherence in the field of anti-terror and to provide support in this direction to member states.

\section{Russia-Spain Cooperation to Counter-Terrorism: Challenges and Legal Approaches}

Internationalization of global terrorism and changeable combination of scenarios of terrorist attacks, expansion of terrorist networks arise significance of bilateral interaction against terrorism. The mechanism of Russia-Spain efforts in terrorism prevention is of big interest due to old joint dialogue, due to transnational activity of terrorist groups in both countries and identity of political views regarding modern challenges and threats. Since 1990s this mechanism is moved to combating terrorism direction, so as Russia and Spain have a congruent understanding of 
terrorist attack and necessity to adhere principles and norms of the UN. Both countries ratified 13 universal anti-terrorism protocols and conventions.

The National Security Strategy of Spain 2013 underlines that Russia is a large neighbor and a key strategic actor of the EU. After terroristic acts in Barcelona and Cambrils in 2017 Spanish Ambassador to Russia Ignacio Ybanez Rubio said: "Unfortunately one has to state that Spain's experience of fighting terrorism is very great and long, but it also shows that terrorism can be fought successfully. We hope that we shall continue this successful experience of fighting terrorism, and other countries will help us including Russia". So Spain hopes to continue the joint fighting against terrorism with Russia, as it has a wide experience in this sphere and it has made a significant contribution to counter-terrorism in the Middle East. In addition, after independence referendum held in Catalonia in 2017, which was not recognized by the government of Spain, as well as by no other country in the world. Russia was one of the first countries that supported the territorial integrity of Spain, the efforts of the Spanish government, stating that all internal problems of Spain should be solved within the framework of the Spanish constitution and legislation.

Despite of the mutual support between Russia and Spain, in the light of freezing of political dialogue between Russia and the West, there is a real risk that the common distrust can have a negative result in combating global terrorism. But nevertheless, the counter-terrorism issue is a core motif for Russia-West cooperation. There are objective reasons for that. "Terrorism will continue to be a threat for the world, Europe, our citizens, our security and our way of life for the foreseeable future. In 2017 while jihadist-inspired attacks increased, so did our preventive actions - with at least 11 attacks foiled. This is the strongest testament to the necessity of working together to defeat terrorism. Europol's annual report leaves no doubt that the problem affects all of us equally, and we can only address it with collective action, unity of purpose, and above all trust. A genuine and effective Security Union in Europe is the surest way to tighten the screws on terrorists until they no longer have space to commit their atrocities", said Dimitris Avramopoulos, European Commissioner for Migration, Home Affairs and Citizenship (Europol, 2018). According to EU Terrorism Situation and Trend Report 2018, the latest trends in international terrorism in Europe are that internet played a significant role in radicalization of some criminal groups, during attacks terrorists preferred for improvised explosive devices, terrorist strategies have further diversified and the threat has increased (EU Terrorism Situation and Trend Report, 2018).

The events in Ukraine and the EU sanctions adopted in 2014 have a negative influence on bilateral relations between Russia and Spain, both from an economic point of view and in terms of cooperation in the area of countering terrorism. Despite the complicated financial and economic situation in the world, the total volume of trade between Russia and Spain in 2013 was 11 billion US dollars, while trade and investment markers grew by $3 \%$. As a result of the EU's sanctions policy towards Russia, trade has decreased from 2013 to 5 billion US dollars by 2017, and the number of Russian tourists visiting Spain from 1.5 million to 1.1 million people a year. In 2018, Russia's Ambassador to Spain, Yu.P. Korchagin, cited a sum of 700 million euros, "which Spain lost as a result of anti-Russian sanctions, as well as counter measures taken by the Russian Federation". However, in 2018, there were some positive trends and prospects for the growth of trade (Anikeeva, 2019). 
Disunity, lack of coordination of actions becomes another threat to each country, as well as the whole world. These factors are beneficial for terrorists and their destructive plans. Therefore, the problem of overcoming any obstacles to bilateral and multilateral mutual measures is extremely relevant now (Shpakovskaya et al, 2017). Spain has never been a full supporter of the EU sanctions against Russia. According to Josep Borrell Fontelles, the Spanish Minister of Foreign Affairs: "Spain is one of the countries that suffered the most from the Russian response to European sanctions. We are more than anyone willing to normalize relations and are working in this direction" (El País, 2018).

Despite the deterioration of bilateral Russian-Spanish relations as a result of the sanctions policy since 2014, there is a mutual interest of the two countries in the joint fight against terrorism, as well as the convergence in the aspect of counter extremism, due to the comparable level and type of terrorist threats.

Terrorism threats in Russia and Spain vary in scale, type and ways of radicalization. After the cold war and starting in the 1990s, Russia has been more exposed to terrorist attacks than Spain (see figure 1) because of terrorist attacks in the North Caucasus. During the same period, there were fewer terrorist attacks in Spain. Since 2012, Russia has ranked higher in the Global terrorism index than Spain (see table 1). In the 2012 Index, Russia was one of the top ten countries in the world in terms of terrorist activity, ranking $9^{\text {th }}$, while in 2014- $11^{\text {th }}$, and in 2015 $-23^{\text {rd }}$, while Spain was ranked $45^{\text {th }}$ position in $2012,69^{\text {th }}$ in 2014 , and $65^{\text {th }}$ in 2015 . However, the gap began to decline. In the Index for 2018, Russia was ranked $34^{\text {th }}$ and Spain $50^{\text {th }}$.

Diagram 1. Dynamics of terrorist attacks in the Russian Federation and in Spain (1990-2017)

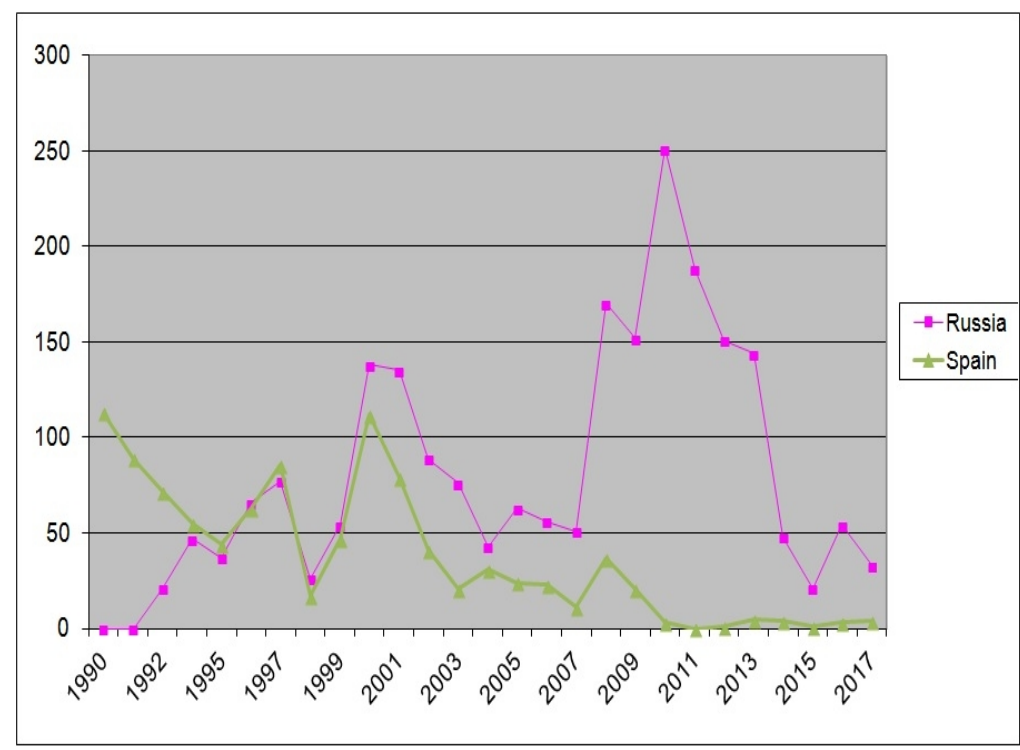

Source: Global Terrorism Database. 
As for the diagram 1, it shows dependence of the number of terrorist acts on a particular period of time (17 years) (see diagram 1). It can be seen that since 1992, there has been observed a starting expansion of terrorist activity in both countries. One more peak of terrorist activity has been noticed in 2000-2001 and in 2010, which can be related to the financial crisis. A decline in terrorist activity has been marked in Russia and Spain from 2004 till 2007. A long period of stabilization has been in Spain from 2007 to 2017, which might be connected with the country's refusal to take part in the Syrian and the Iraqi campaigns. The greatest number of terrorist attacks in Russia was in 2010. As shown in diagram 1 the dynamics of terrorist attacks in Spain systematically reduces while in Russia it develops in chaotic way.

An insignificant difference in the scale and scope of threats can be seen in the lists of terrorist organizations of the EU and the Russian Federation. The official lists of terrorist organizations of the Russian Federation and the European Union are dominated by radical Islamist groups. Thus, the Russian list of foreign terrorist organizations, as of March 14, 2019 noted 30 organizations, most of which are Islamist (Federal Security Service of the Russian Federation, 2019), while in the list of the Council of the European Union as of January 8, 2019 there are only 21 terrorist organizations (EUR-Lex, 2019) with a similar predominance of radical Islamist organizations.

ISIS is a serious threat to both Russia and Spain. For the Russian Federation, the danger posed by this international Islamist terrorist organization is not limited only to conflicts in the North Caucasus (Stepanova, 2017). ISIS has initiated small radical cells outside the region and recruited individuals in different parts of the country. ISIS initiated small radical cells outside this region and recruited individuals in different parts of the country. This type of threat resembles the phenomenon problem of individual terrorists and network agents prevalent in Europe and the United States.

Russia's practical experience in combating terrorism was based on the antiinsurgency campaign in the North Caucasus, as well as a militarized strategy for participating in the Middle East settlement, while in Spain this experience included both political (granting broad autonomy to the region) and a strong security force (the creation of anti-terrorist armed groups and the activities of special services) in the fight against Basque separatism (Mihajlin, 2016). With regard to participation in the stabilization of the situation in the Middle East, Spain has long been neutral, refraining from military operations in favor of assistance in the training of soldiers.

However, the Russian Federation began to pay more attention to the causes and conditions of terrorism, as well as preventive measures, while Spain in the new counter-terrorism strategy focused on the processes of de-radicalization, paying great attention to former members of ISIS and Al-Qaeda, who are returning from conflict zones, prisons, where petty criminals become radical.

Among common initiatives realized between Russia and Spain it is worth to mention the establishment of a joint cybersecurity group to prevent diplomatic relations from being damaged by the results of misinformation (The Moscow Times, 2018). On the one hand, this agreement intensifies cooperation in information technologies security on the territory of two countries, on the other hand, there is a danger that the Russian-Spanish project may enter into a confrontation with the EU policy of sanctions. Regarding the confrontation between Moscow and Brussels, the Spanish leadership takes a generally 
neutral attitude, refraining from sharp statements and relying on possible positive developments in the general format of Russia-EU relations.

The Foreign Policy Concept of Russia defines anti-terrorist measures as major national concern and key priority in the international security vector. Condemning all terrorist acts in all their formats, Russia actively participates in promoting the idea of joining efforts of all countries and of the world community to prevent this threat, including a liquidation of sources of the terrorist organizations financing (Foreign Policy Concept of the Russian Federation, 2016).

Table 1. Ranking of Russia and Spain according to the Global Terrorism Index for 2012-2018

\begin{tabular}{|l|r|r|r|r|r|r|}
\hline \multirow{2}{*}{ Country } & \multicolumn{7}{|c|}{ Year } \\
\cline { 2 - 8 } & 2012 & 2014 & 2015 & 2016 & 2017 & 2018 \\
\hline Russian Federation & 9 & 11 & 23 & 30 & 33 & 34 \\
\hline Spain & 45 & 69 & 65 & 89 & 85 & 50 \\
\hline Total number of countries & 158 & 162 & 162 & 163 & 163 & 163 \\
\hline
\end{tabular}

Source: Global Terrorism Index reports (2012-2018), economicsandpeace.org

The Criminal Code of the Russian Federation specifies terrorism as "the carrying out of an explosion, arson or other actions intimidating the population, and creating the threat of human death, of infliction of significant property damage or the onset of other grave consequences, for the purpose of influencing the taking of a decision by authorities or international organizations, and also the threat of commission of the said actions for the same purposes" (Criminal Code of Russia, 1996). As for the Criminal Code of Spain (1995), it does not have an official interpretation of terrorism, but this term is often used within the context of criminal offence or threat.

The National Security Strategy of Spain 2013 considers terrorism among one of the 12 threats to national security together with cyberattacks, armed conflicts and organized crime. It includes the following definition of terrorism: "A direct threat to the life and security of citizens; it aims to undermine our democratic institutions and jeopardises our vital and strategic interests, infrastructures, supplies and critical services. Preventing, impeding and defeating terrorism, whatever its origin, is a priority aim of the Government" (The National Security Strategy of Spain, 2013). As can be seen, Russia and Spain understand terrorism not just as a complex threat to security, but as a criminal offence as well.

In 2006 in Madrid Russia and Spain formulated a joint vision of terrorism which was stated by V. Putin, the President of Russia, and J.L.R. Zapatero, former Prime Minister of Spain: "Terrorism is one of the most serious threats to international peace, security and stability, social and economic development of all countries; it aims to destroy coexistence, mutual understanding, and enrichment of civilizations, cultures, and nations. Any attempts to identify terrorism with any particular nation, culture, or religion, shall not be tolerated. Terrorism is a violation 
of the fundamental human rights, most significantly, of the right to life and the right to live without fear" (Ministry of Foreign Affairs of the Russian Federation, 2006). The mutual understanding of terrorism as a threat and a destabilization in the world was adopted on a bilateral level, together with the special accent to the human rights and fundamental freedoms protection.

The Russian national anti-terrorism legal system is more extensive, as compared to Spain. Russia ratified over 40 legal documents dedicated to counter-terrorism and extremism aspects (the President's Decrees, Federal Laws, Government Regulations, and Codes). Spain adopted 11 documents (Committee of Experts on Terrorism, 2013). The Russian legislation in this area is characterized by a larger scope of legal documents referred to counter-terrorism and extremism measures, while in comparison, the Spanish laws are aimed at fighting local terrorism of a nationalist nature (Gómez Abeja, 2018). The Federal Law "Concerning the Combating of Terrorism" (2006) and Counter-Extremism Strategy of the Russian Federation up to 2025 (2014) are addressed to the analysis of "the extremist activity of nationalist, religious, ethnic, or other organizations and structures", which destabilize domestic political and social environment of the state.

Art. 3 of the Federal Law determines terrorism as "the ideology of violence and practice of influence on decision-making by public authorities, local selfgovernment bodies or international organizations related to frightening the population and/or other forms of unlawful violent actions" (Federal Law "Concerning the Combating of Terrorism", 2006). Spain does not have a separate law regarding the combating of terrorism, but anti-terrorism issues, and penal measures for terrorist crime are listed in the Criminal Code of Spain, including sanctions as well as the terms and conditions of declaring any act as a terrorist attack (Criminal Code of Spain, 1995). Counter-terrorist pact signed in 2000 is the agreement between the leading Spanish parties to avoid using counter-terrorism methods for political privileges. Besides, Spain has the National Security Law presenting the national security in various aspects, and adopting it for government entities, civil society, etc.

Basis of the Russian-Spanish relations comprises over 50 interstate, intergovernmental, and interdepartmental agreements. A number of them can be accessed on the website of the Russian embassy in Spain. Since 1990s a number of the legal framework of cooperation with regard to mutual assistance in counterterrorism, organized crime, and drug traffic efforts (Embassy of the Russian Federation in Madrid, 2017) have emerged. From 1994 to the present day 8 agreements with regard to counteraction of terrorism were implemented, and 2 of them (1996 Treaty on rendering legal assistance in criminal matters and also the 1999 Agreement between the Government of the Russian Federation and the Government of the Kingdom of Spain on cooperation with regard to informatization matters), while being of great importance with regard to the counter-terrorist agenda, are approved but are not working, as is stated on the website of the MFA of Russia (The Ministry of Foreign Affairs of the Russian Federation, 2017). Despite the prioritization of the threat on the part of these two countries in relation to domestic and foreign policy, considering the scope of the threat, few counter-terrorist agreements and contracts have been implemented. The foregoing does not correspond to the current interaction potential between the states. 
Agreement between the Government of the Russian Federation and the Government of the Kingdom of Spain for crime control (1999) marked a new collaboration stage between the countries. The purpose of this Agreement was development and acceleration of the efficiency of two-sided cooperation with regard to security. A relevant Road map was adopted in July 1999. It included mechanisms of mutual exchange of information, the cooperation with regard to prevention, investigation, and combating with organized criminal activity, and onsite training, including sharing experiences related to successful problem solving by the law enforcement agencies.

The establishment of the Russian-Spanish interdepartmental anti-terrorism working group in 2004 serving as the platform for an open dialogue, drawing up of joint arrangements, and elaborating of bilateral initiatives, became a striking example of willingness to eradicate terrorism together. Cooperation with regard to counter-terrorism efforts intensified through latest meetings and conferences of the official circles: i.e. the meeting of the Russian-Spanish anti-terrorism working group in May 2015 in Madrid; in 2016 this meeting took place in Moscow under co-chairmanship of O.V. Syromolotov, Deputy Minister of Foreign Affairs of the Russian Federation, and Mr. E. Mora Benavente, Director-General for Foreign Policy and Security of Spain.

Russia and Spain support the principles of the UN anti-terrorism conventions, strategies and protocols, promote counter-terrorism efforts within the European Union. In particular, both countries welcomed ratification of the International Convention for the Suppression of Acts of Nuclear Terrorism (2005), the Council of Europe Convention on the Prevention of Terrorism (2005), and the Security Council resolutions 1566, which organized a working group for practical measures consideration to be applied to the involved in terrorist activity apart from Al-Qaeda and the Taliban, and the Security Council resolution 1624 criminalizing abetment to terrorist attacks.

The cooperation of the two-sided Russian-Spanish has been drawn up by similarity of points of view with regard to the key anti-terrorist issues; both countries have certain differences in terms of the approaches to the formation of a relevant national legal system, which affected the bilateral legal base which is in need of improvement. Best domestic counter-terrorism practices may be used in bilateral cooperation. However, much is to be done by Russia and by Spain in order to achieve the level of counter-terrorism cooperation for further strategic partnership. It also seems advisable to activate exchanging of best practices as well as information with this regard.

A comparative analysis of approaches, terrorist threats and radicalization in Russia and Spain leads to two key conclusions:

1) Despite the fact that Russia was more susceptible to terrorist attacks after the end of the Cold War, the EU pays more attention to the topic of de-radicalization, preventive and non-military measures to counter extremism and terrorism.

2) Despite the existing obstacles in the bilateral cooperation between Russia and Spain (sanctions, an atmosphere of mistrust, the problem of human rights violations and data collection), commonality in understanding the seriousness of the terrorist threat, as well as a comparable level and similar type of threat for the 
two countries can become the basis and catalyst of the Russian-Spanish interaction on anti-terror.

\section{Conclusion}

Within the context of the growing threat of terrorism influencing over the international security, three major tendencies may be emphasized: the UN counterterrorism strategy fails to achieve optimum effect in fighting international terrorism; the international legal counter-terrorism framework is being functioning in the lack of a unified approach to the terminology of terrorism; the level of international cooperation between the countries doesn't correspond the transnational character of terrorism; conflicts with regional and international dimensions in Libya, Afghanistan, Iraq, Syria have been going on for a long time. This is used by terrorist groups - not only those involved in internal conflicts, but also more and more foreign terrorist groups.

The changeable context of the international security resulted in the idea of human protection from interrelated challenges of the globalized world. In this line, international control over terrorism is possible via using an "all-ofgovernment", "all-of-society" and "all-of-UN" approach. Government participation in counter-terrorism performs a key function in normalizing the relations within the system of regional, multinational, and international interaction in the formats of adopting agreements, developing road maps, concepts and strategies and realizing anti-terrorist projects.

The events in Ukraine and the EU sanctions started in 2014 have a negative influence on bilateral relations between Russia and Spain, both from an economic point of view and in terms of cooperation in the sphere of countering terrorism. Despite the fact that many European countries, such as Italy, Greece, Austria, Hungary, Spain and others, are experiencing significant disruptions in their economies because of the response of Russian counter-sanctions, they will not be able to soften or at least partially mitigate them. In the light of freezing of political dialogue between Russia and the West, there is a real risk that the common distrust can have a negative result in combating global terrorism. Disunity, lack of coordination of actions becomes another threat to each country, as well as the whole world. These factors are beneficial for terrorists and their destructive plans. The policy of confrontation in relations with Russia, whose participation is necessary to solve many international problems, should be replaced by the logic of cooperation.

Counter-strategy needs the same integrated system of reaction. The absence of a unified approach to terrorism terminology regarding international terrorism, terrorist attack and terrorism on an international level, problems with adopting national legal frameworks to the international legislation catalyzes the development of new, and more effective counter-terrorism formats and intensifies networking on local, regional, and international levels that might provide a chance to stay a step ahead of terrorist plans rather than to take post factum measures.

Taking into account, that the core responsibility for countering terrorism rests with sovereign states, development of Russia-Spain strategic collaboration in 
combating terrorism intensifies multipartite interaction in this area. However, despite of the accumulated experience in various spheres, the bilateral counterterrorism legal framework does not correlate with the current cooperation potential between Russia and Spain, and requires further updating.

As for future forecasts, first, the establishment of a bilateral dialogue between Russia and Spain, including a successful cooperation in the fight against terrorism, which will depend on solving the problem of sanctions and counter-sanctions. To make predictions on this issue is quite difficult, as some researchers believe that the EU at this stage faces a choice: to support Russia and thus go against US policy or continue to follow the policy of Washington (Emelina, 2016).

Secondly, the effectiveness of Russian-Spanish cooperation in the field of counter-terrorism will most likely be determined by the interest of the two countries in exchanging best practices in this area. For example, Russia could learn from the experience of working with victims of terrorism, while Spain could benefit from Russia's experience of living closely and interacting with a large indigenous Muslim population.

\section{Bibliography}

Agreement between the Government of Russia and the Government of the Kingdom of Spain about Cooperation in Fighting with Crime (1999). Available at: http://docs.cntd.ru/document/901711861 [Last consulted: March 18, 2019].

Anikeeva, N.E. (2019): Russia-Spain: Dialogue with Accents. MGIMO Website. Available at: https://mgimo.ru/about/news/experts/rossiya-ispaniya-dialog-s-aktsentami/ [Last consulted: March 18, 2019]

Aoláin, F.N. (2018): European Counter-Terrorism Approaches: A Slow and Insidious Erosion of Fundamental Rights, Just Security, Available at:

https://www.justsecurity.org/61086/european-counter-terrorism-approaches-slowinsidious-erosion-fundamental-rights/

[Last consulted: June 18, 2019]

Argomaniz, J. (2015): State Responses to Victims of Terrorism Needs in Spain, Available at: https://www.researchgate.net/publication/ 272176644_State_Responses_to_Victims_of_Terrorism_Needs_in_Spain. [Last consulted: June 17, 2019] doi: 10.1057/9781137347114_6

Badey, T. J. (1998): "Defining international terrorism: A pragmatic approach", Terrorism and Political Violence, Vol. 10, No. 1, pp. 90-10 https://doi.org/10.1080/09546559808427445

El País (2018): España y Rusia pactan un foro de ciberseguridad contra la desinformación, Avaliable at: https://elpais.com/politica/2018/11/06/actualidad/1541514798_739002.html [Last consulted: March 17, 2019]

Embassy of the Russian Federation in Madrid (2017): Bilateral Agreements of Russia and Spain, Available at: https://spain.mid.ru/web/spain_ru/soglasenia [Last consulted: March 17, 2019] 
European Commission (2016): Communication from the Commission to the European Parliament, the European Council and the Council - delivering on the European Agenda on Security to fight against terrorism and pave the way towards an effective and genuine Security Union, COM 230 final, pp. 2, 9.

Committee of Experts on Terrorism (2013): Spain's Profile on Counter-Terrorist Capacity, Available at:

https://rm.coe.int/168064102c

[Last consulted: March 17, 2019]

Criminal Code of Spain (1995): Available at:

https://wipolex.wipo.int/en/text/126619

[Last consulted: March 18, 2019]

EUR-Lex (2019): Council Decision 2019/25 amending and updating the list of persons, groups and entities subject to Articles 2, 3 and 4 of Common Position 2001/931/CFSP on the application of specific measures to combat terrorism, and repealing Decision (CFSP) 2018/1084, Available at:

https://eur-lex.europa.eu/legal-content/en/TXT/HTML/?uri=CELEX:32019D0025\&from=EN [Last consulted: June 18, 2019]

Criminal Code of the Russian Federation (1996): Available at: https://www.wipo.int/edocs/lexdocs/laws/en/ru/ru080en.pdf

[Last consulted: March 17, 2019]

Declaration on Strategic Partnership between the Russian Federation and the Kingdom of Spain (2009): Available at:

https://spain.mid.ru/web/spain_ru/soglasenia

[Last consulted: March 19, 2019]

Emelina, I.A. (2016): "Russia-European Union Relations in the Context of Mutual Sanctions", Actual Problems of Contemporary International Relations, No. 7, pp. 34-41.

Europol (2018): Terrorist Threat in the EU Remains High Despite the Decline of IS in Iraq and Syria, Available at:

https://www.europol.europa.eu/newsroom/news/terrorist-threat-in-eu-remains-highdespite-decline-of-in-iraq-and-syria

[Last consulted: March 19, 2019].

EU Terrorism Situation and Trend Report (2018): Available at:

https://www.europol.europa.eu/newsroom/news/terrorist-threat-in-eu-remains-highdespite-decline-of-in-iraq-and-syria

[Last consulted: March 19, 2019]

Federal Law of Russia “On Combating Terrorism” (2006): Available at: http://www.mchs.gov.ru/law/Federalnie_zakoni/item/5378619

[Last consulted: March 19, 2019]

Federal Security Service of the Russian Federation (2019): Unified Federal List of Organizations, including Foreign and international organizations recognized in accordance with the legislation of the Russian Federation as terrorist, Available at: http://www.fsb.ru/fsb/npd/

[Last consulted: June 19, 2019]

Foreign Policy Concept of the Russian Federation (2016): Available at:

http://www.mid.ru/en/foreign_policy/official_documents/-/asset_publisher/

CptICkB6BZ29/content/id/2542248

[Last consulted: March 17, 2019] 
Global Terrorism Database (2019): Available at:

https://www.start.umd.edu/gtd/search/Results.aspx?

start_yearonly $=\&$ end $\_$yearonly $=\&$ start_year $=2000 \&$ start_month $=1 \&$ start_day $=1 \&$ end year $=2000 \&$ end month $=12 \&$ end day $=31 \&$ asmSelect $0=\&$ country $=167 \&$ country $=185 \&$ asmSelect $1=\& d \operatorname{dtp} 2=$ all\&success $=$ yes $\&$ casualties_type $=b \&$ casualties_max $=$

[Last consulted: March 17, 2019]

Global Terrorism Index (2012, 2014, 2015, 2016, 2018): Available at:

http://visionofhumanity.org/app/uploads/2018/12/Global-Terrorism-Index-2018-1.pdf

[Last consulted: March 15, 2019]

Gómez Abeja, L. (2018): "'Passive Indoctrination' as a Terrorist Offense in Spain - A Regression from Constitutional Rights?", VerfBlog, Available at:

https://verfassungsblog.de/passive-indoctrination-as-a-terrorist-offense-in-spain-a-

regression-from-constitutional-rights/

https://dx.doi.org/10.17176/20180511-104134

Mihajlin, I. V. (2016): "The fighting of Russia and Spain Against Terrorism: a Comparative Analysis", Vlast', Vol. 24, no. 9, pp. 215-222.

Official Website of the President of Russia (2009): Dmitry Medvedev met with Prime Minister of Spain Jose Luis Rodriguez Zapatero, Available at:

http://kremlin.ru/events/president/news/5465

[Last consulted: March 15, 2019]

Project of Federal Law of Russia "About Fighting Organized Crime" (1995): Available at:

http://www.consultant.ru/cons/cgi/online.cgi?

base $=$ PRJ\&n=21973\&req $=$ doc $\# 03723641243886272$

[Last consulted: March 15, 2019]

Rapoport, D. C. (2017): Terrorism as a Global Wave Phenomenon: An Overview. https://doi.org/10.1093/acrefore/9780190228637.013.299

Report of the United Nations High-level Conference on Counter-terrorism (2018), Available at:

https://www.un.org/counterterrorism/ctitf/sites/www.un.org.counterterrorism.ctitf/files/ Report_UNHLC_FINAL_WEB.pdf

[Last consulted: March 17, 2019]

Shpakovskaya, M., S. Bokeriya and M. Vezuina (2017): Increased Terrorist threat in Europe and The EU's Response, Analele Universitatii din Craiova Istorie, Vol. 31, No. 1 , pp. 105-116.

Stepanova, E. (2017): How and Why Russia and the United States can Cooperate in Countering Terrorism, Russia in Global Affairs, Available at:

https://globalaffairs.ru/PONARS-Eurasia/Kak-i-pochemu-Rossiya-i-SShA-mogutsotrudnichat-v-protivodeistvii-terrorizmu-18732

[Last consulted: June 17, 2019]

Strategy Against Extremism in the Russian Federation till 2025 (2014): Available at: http://www.consultant.ru/cons/cgi/online.cgi?

req $=$ doc $\&$ base $=$ LAW $\& n=194160 \&$ fld $=134 \& d s t=1000000001,0 \&$ rnd $=0.598080724917$ $3735 \# 0$

[Last consulted: March 17, 2019]

Tarasenko, P. (2019): "Islamists Enter the Stock Market", Kommersant, Available at: https://www.kommersant.ru/doc/4005024?query=\%D0\%98\%D1\%81\%D0\%BB $\%$ D0\%B0\%D0\%BC\%D0\%B8\%D1\%81\%D1\%82\%D1\%8B\%20\%D0\%B2\%D1\%8B 
$\% \mathrm{D} 1 \% 85 \% \mathrm{D} 0 \% \mathrm{BE} \% \mathrm{D} 0 \% \mathrm{~B} 4 \% \mathrm{D} 1 \% 8 \mathrm{~F} \% \mathrm{D} 1 \% 82 \% 20 \% \mathrm{D} 0 \% \mathrm{BD}$

$\%$ D0\%B0\%20\%D1\%84\%D0\%BE\%D0\%BD\%D0\%B4\%D0\%BE\%D0\%B2\%D1\%8B

$\% \mathrm{D} 0 \% \mathrm{~B} 9 \% 20 \% \mathrm{D} 1 \% 80 \% \mathrm{D} 1 \% 8 \mathrm{~B} \% \mathrm{D} 0 \% \mathrm{BD} \% \mathrm{D} 0 \% \mathrm{BE} \% \mathrm{D} 0 \% \mathrm{BA}$

[Last consulted: June 21, 2019]

The Council of Europe Convention on the Prevention of Terrorism (2005): Available at: https://www.cbr.ru/today/anti_legalisation/ec/EC2005.pdf

[Last consulted: March 17, 2019]

The European Union's Policies on Counter-Terrorism. Relevance, Coherence and Effectiveness (2017): Available at:

http://www.europarl.europa.eu/RegData/etudes/STUD/2017/583124/IPOL_STU

$\% 282017 \% 29583124$ EN.pdf

[Last consulted: June 20,2019$]$

The Ministry of Foreign Affairs of the Russian Federation (2006): Statement on Shared Action in Combating Terrorism, Available at:

http://www.mid.ru/web/guest/foreign_policy/news/-/asset_publisher/cKNonkJE02Bw/ content/id/413722

[Last consulted: March 17, 2019]

The Ministry of Foreign Affairs of the Russian Federation (2019): Bilateral Agreements of

Russia and Spain. Available at:

http://www.mid.ru/foreign_policy/international_contracts/2_contract/-/storage-viewer/

bilateral/page-1?

_storageviewer_WAR_storageviewerportlet_sdAttr_signingDate_key_field $=\&$ _storage viewer_WAR_storageviewerportlet_advancedSearch $=$ false\&_storageviewer_WAR_sto rageviewerportlet_keywords $=\% \mathrm{D} 0 \% 98 \% \mathrm{D} 1 \% 81 \% \mathrm{D} 0 \% \mathrm{BF} \% \mathrm{D} 0 \% \mathrm{~B} 0 \% \mathrm{D} 0 \% \mathrm{BD}$

$\% \mathrm{D} 0 \% \mathrm{~B} 8 \% \mathrm{D} 1 \% 8 \mathrm{~F} \&$ storageviewer_WAR_storageviewerportlet_sdAttr_subjects_key field $=\&$ \& storageviewer_WAR_storageviewerportlet_dateEnd $=\&$ _storageviewer_WAR _storageviewerportlet_dateStart=\&_storageviewer_WAR_storageviewerportlet_andOpe rator=1\&_storageviewer_WAR_storageviewerportlet_sdAttr_validity_key_field $=\&$ _sto rageviewer_WAR_storageviewerportlet_content $=\&$ _storageviewer_WAR_storageview erportlet_title $=\&$ _storageviewer_WAR_storageviewerportlet_sdAttr_countries_key_fiel $\mathrm{d}=$ \&_storageviewer_WAR_storageviewerportlet_action $=$ search\&_storageviewer_WAR _storageviewerportlet_sdAttr_orgs_key_field=

[Last consulted: March 17, 2019]

The Moscow Times (2018): Russia and Spain Agree to Cooperate on Cyber Security, Available at:

https://www.themoscowtimes.com/2018/11/07/russia-and-spain-agree-to-cooperate-oncyber-security-fight-fake-news-a63417

[Last consulted: March 17, 2019]

The National Security Strategy of Spain (2013): Avaliable at:

http://www.lamoncloa.gob.es/documents/estrategiaseguridad_baja_julio.pdf

[Last consulted: March 15, 2019]

Treaty of Friendship and Cooperation between the Russian Federation and the Kingdom of Spain (1994): Available at:

http://nic.gov.ru/ru/docs/foreign/collaboration/agreem_coop_Spain_1994

[Last consulted: March 15, 2019]

United Nations in the Russian Federation (2018): Statement by Mr. Vladimir Ivanovich Voronkov, Under-Secretary-General for Counter-Terrorism at the International 
Research-To-Practice Conference on Priorities of International Cooperation in Countering Extremism and Terrorism; Available at:

http://www.unrussia.ru/en/taxonomy/term/4/2018-04-05

[Last consulted: March 17, 2019]

United Nations Development Programme, UNDP (1994): Human Development Report 1994: New Dimensions of Human Security, Available at:

http://hdr.undp.org/sites/default/files/reports/255/hdr_1994_en_complete_nostats.pdf [Last consulted: March 16, 2019]

United Nations Office of Counter-Terrorism (2019a): International Legal Instruments, Available at:

http://www.un.org/en/counterterrorism/legal-instruments.shtml

[Last consulted: March 16, 2019]

United Nations Office of Counter-Terrorism (2019b): Resolutions, Available at: https://www.un.org/counterterrorism/ctitf/en/uncct/resolutions [Last consulted: March 16, 2019]

United Nations Official Website (2005): International Convention for the Suppression of Acts of Nuclear Terrorism, Available at:

https://treaties.un.org/doc/db/terrorism/english-18-15.pdf

[Last consulted: March 16, 2019]

United Nations Official Website (2001): Security Council Resolution 1373, Available at: http://www.un.org/en/sc/ctc/specialmeetings/2012/docs/United\%20Nations\%20Security \%20Council\%20Resolution\%201373\%20(2001).pdf

[Last consulted: March 16, 2019]

United Nations Official Website (2004): Security Council Resolution 1566 on Threats to International Peace and Security Caused by Terrorist Acts, Available at:

https://www.un.org/ruleoflaw/blog/document/security-council-resolution-1566-2004on-threats-to-international-peace-and-security-caused-by-terrorist-acts/

[Last consulted: March 16, 2019]

United Nations Official Website (2005): Security Council Resolution 1624, Available at: https://documents-dds-ny.un.org/doc/UNDOC/GEN/N05/510/52/PDF/N0551052.pdf? OpenElement

[Last consulted: March 16, 2019]

United Nations Security Council (2017): Security Council Resolutions, Available at: http://www.un.org/en/sc/documents/resolutions/

[Last consulted: March 16, 2019] 